3. Гасанов 3.М. Плодоводство (лабораторный практикум). Баку: МБМ, 2010, 343 с.

4. Методические рекомендации по производственному сортоиспытанию косточковых плодовых культур / Сос. Косых С.А. Ялта: Государственный Никитский ботанический сад, 1984, 38 с.

5. Методы биохимического исследования растений / Под ред. А.М.Ермакова. Л.: Агропромиздат, 1987, 430 с.

6. Плешков Б.П. Практикум по биохимии растений. М.: Колос, 1976, 256 с.

7. Помология: Т. 3, Симиренко Л.П. Киев: Урожай, 1972, 442 с.

8. Самигуллина, Н.С. Практикум по селекции и сортоведению плодовых и ягодных культур: Учеб. Изд. Мичуринск: Мич ГАУ, 2006, 197 с.

9. Учеты, наблюдения, анализы, обработка данных в опытах с плодовыми и ягодными растениями (методические рекомендации) / Под ред. Карпечука Г.К. и Мельника А.В. Уман: Уман с.-х. ин-т., 1987, 115 с.

DOI 10.18699/GPB2020-81

\title{
Оценка образцов картофеля различного эколого-географического происхождения в условиях Новосибирского Приобья
}

Батов А.С. *, м.н.с., Сафонова А.Д., с.н.с., Гуреева Ю.А., агроном первой категории, Орлова Е.А., в.н.с.

Сибирский научно-исследовательский институт растениеводства и селекиии - филиал ИЦиГ СО РАН, Новосибирск, Россия.

*e-mail: alexandr-batov@mail.ru

В результате эколого-географического испытания 60сортов и гибридов картофеля отечественной селекции выделены образиы разных групп спелости с высокой продуктивностью. В ходе исследования быливыделены наиболее урожайные (Метеор, Любава, Люкс, Удача, Ильинский, Невский, С112-03, Сафо, Танай, Гусар, Златка и Никулинский) иустойчивые к болезням (Удача, Кузнечанка, Невский, Крепыш, Лина, Сударыня, Никулинский, Сафо и Юна) сорта. По комплексу хозяйственно-ценных признаков выделились сорта: Любава, Невский, Никулинский, Сафо и Удача.

Ключевые слова: картофель, сорт, урожайность, сохранность, устойчивость.

\section{Assessment of potato samples of different ecological-geographic origin under the conditions of Novosibirsk part of $\mathrm{Ob}$ region}

Batov A.S., Junior Researcher, Safonova A.D. Senior Researcher, Gureeva IU.A., Agronomist, Orlova E.A., Leading Researcher, Siberian Research Institute of Plant Production and Breeding - Branch of the Institute of Cytology and Genetics, Siberian Branch of the Russian Academy of Sciences, Novosibirsk, Russia, e-mail: 
alexandr-batov@mail.ru.

The samples of different ripeness groups with high productivity were selected from 60 potato varieties and hybrids of the Russian selection, as a result of ecological-geographic testing. As a result, most productive (Meteor, Liubava, Liuks, Udacha, Ilinskii, Nevskii, S-112-03, Safo, Tanai, Gusar, Zlatka \& Nikulinskii) and disease resistant (Udacha, Kuznechanka, Nevskii, Krepysh, Lina, Sudarynia, Nikulinskii, Safo \& Iuna) varieties were noted. In terms of economically valuable traits, samples Liubava, Nevskii, Nikulinskii, Safo \& Udacha were noted.

Key words: potato, variety, productivity, preservation, resistance.

Свойства картофеля как ценного продукта питания человека, в котором в оптимальном соотношении содержатся органические и минеральные вещества, известны давно. В нем содержатся практически все химические элементы, необходимые человеку. Благодаря своим пищевым качествам картофель стал продуктом почти повседневного употребления [1].

Уровень душевого потребления картофеля в России остается одним из самых высоких в мире, больше его едят только в Беларуси и Украине. Сибирский федеральный округ занимает первое место по потреблению картофеля на душу населения в Российской Федерации, в среднем на одного человека приходится 134 кг в год. В Новосибирской области этот показатель на уровне 108 кг. Между тем уровень урожайности, переработки и сохранности картофеля в нашей стране - один из самых низких в европейском сообществе [2].

Цель работы - на основе оценки сортов российской селекции в условиях лесостепи Приобья выделить высокопродуктивные образцы картофеля для внедрения в сельскохозяйственное производство региона.

Материалы, условия и методика проведения опытов. Экспериментальная часть работ проводилась на опытных полях СибНИИРС в условиях лесостепной зоны Приобья. Метеоусловия в годы исследований (2016-2018) характеризовались теплой и влажной весной, кроме мая 2018 года, который отличался низкой среднесуточной температурой до $7^{\circ} \mathrm{C}$, что отодвинуло посадку на конец первой декады июня. Летние месяцы вегетации в годы исследований характеризовались благоприятными условиями для развития растений. Температурный режим был на уровне и чуть выше средней многолетней. Самым благоприятным был 2016 год, в этом году влагообеспеченность в целом за вегетацию была ниже средней многолетней на $24 \%$, но в июле (когда идет закладка клубней) она составила 126 \% к норме. Это дало возможность растениям картофеля оптимально реализовать свой потенциал. Повышенная влагообеспеченность на 130-160 \% к норме в июле и августе 2017 года привела к эпифитотийному развитию фитофтороза на вегетирующих растениях и во время хранения.

Материалом исследований являлись от 40 сортообразцов в 2016 году 
и до 60 сортов в 2017 и 2018 годах. Оздоровленные сорта и гибриды картофеля, полученные из различных географических точек России.

Методика проведения полевого опыта, схема высадки опытных образцов, размещения опытного участка, учеты и наблюдения проведены по методике разработанной заведующим отделом генетических ресурсов картофеля ВИР С.Д. Киру, также были использованы методологические положения ВНИИКХ под редакцией А.Э. Шабанова по проведению эколого-географического испытания сортов и гибридов картофеля $[3,4]$. Для статистической обработки результатов использовали методику полевого опыта Б.А. Доспехова [5]. Клубневой анализ на устойчивость к болезням хранения выполнен в лаборатории иммунитета.

Результаты и обсуждение. Результаты исследования показали, что общая продуктивность у 80 \% российских образцов превысила 35 т/га. У 35 образцов потенциал продуктивности более 40 т/га (таблица).

Таблица - Сорта картофеля, выделившиеся по хозяйственно ценным показателям при массовой уборке, 2016-2018 гг.

\begin{tabular}{|c|l|c|c|c|c|c|}
\hline \multirow{2}{*}{$№$} & \multirow{2}{*}{ Образец } & Группа & Средняя масса & Товарность, & \multicolumn{2}{|c|}{ Урожай } \\
\cline { 6 - 7 } & & спелости & 1 клубня, г & У & г/куст & т/га \\
\hline 1 & Метеор & 01 & $140^{*}$ & 90 & $1288^{*}$ & $45^{*}$ \\
\hline 2 & Любава & 03 & 129 & 88 & $1351^{*}$ & $47^{*}$ \\
\hline 3 & Люкс & 03 & 117 & 89 & $1353^{*}$ & $47^{*}$ \\
\hline 4 & Удача & 03 & 123 & 84 & $1397^{*}$ & $49^{*}$ \\
\hline 5 & Ильинский & 04 & 92 & 77 & $1444^{*}$ & $51^{*}$ \\
\hline 6 & Невский & 04 & 119 & 81 & $1329^{*}$ & $47^{*}$ \\
\hline 7 & С-112-03 & 04 & 76 & 77 & $1361^{*}$ & $48^{*}$ \\
\hline 8 & Сафо & 04 & 103 & 91 & $1361^{*}$ & $48^{*}$ \\
\hline 9 & Танай & 04 & 129 & 79 & $1378^{*}$ & $48^{*}$ \\
\hline 10 & Гусар & 05 & 102 & 94 & $1302^{*}$ & $46^{*}$ \\
\hline 11 & Златка & 05 & 86 & 92 & $1359^{*}$ & $48^{*}$ \\
\hline 12 & Никулинский & 06 & 117 & 83 & $1285^{*}$ & $45^{*}$ \\
\hline 13 & Ред Скарлетт (Ст) & 03 & 118 & 80 & 785 & 27 \\
\hline & НСР 05 & & 16 & & 142 & 5 \\
\hline
\end{tabular}

*превышение над стандартом статистически значимо.

Двенадцать образцов имеют продуктивность равную или выше 45 т/га. Среди них оказались очень ранний сорт Метеор, три раннеспелых: Любава, Люкс, Удача; пять среднеранних: Ильинский, Невский, С-112-03, Сафо, Танай; два среднеспелых: Гусар и Златка; и среднепоздний сорт Никулинский. Выше всех по урожаю оказались сорта картофеля Ильинский и Удача, продуктивность которых составила 49 и 51 т/га соответственно. Средняя масса клубня у них, от 76 г у гибрида С-112-03 до 140 г у сорта Метеор. Товарность у выделившиеся образцов от 77 \% у Ильинского до 94 \% у сорта Гусар. 
Максимальное поражение клубней фитофторозом и фузариозными гнилями отмечали в 2017-2018 гг., видами парши в 2016 году. Проведенный клубневой анализ сортообразцов ЭГИ за 2016-2018 гг. позволил выделить образцы, обладающие резистентностью к различным грибным заболеваниям.

По устойчивости к видам парши выделились:

- к парше обыкновенной 13 образцов: Г 06-08-2015, Гусар, Крепыш, Ломоносовский, Регги, Сударыня, Златка, Фаворит, Г 3-43-2, Саровский, Вираж, Жигулевский и Лина с устойчивостью 8-9 баллов;

- устойчивость к серебристой парше за годы испытаний отмечена на 6 образцах: Жигулевский, Гулливер, Гусар, Саровский, Вираж и Сафо;

- относительно высокой степенью устойчивости к ризоктониозу обладают 9 сортов: Златка, Чароит, Любава, Метеор, Накра, Никулинский, Г 343-2, Жигулевский, Сафо с устойчивостью - 7 баллов. Самым невосприимчивым к ризоктониозу себя показал сорт Танго с девятибалльной оценкой устойчивости.

За годы исследований не отмечено поражение клубней фитофторозом на сортах: Удача, Кузнечанка, Невский, Жигулевский. Относительной устойчивостью к фитофторозу обладали сорта Вымпел, Г 3-43-2, Любава, Крепыш, Саровский, Вираж, Лина, Никулинский, Сафо, Юна, Сударыня с оценкой устойчивости 7-8 баллов.

По устойчивости к смешанным гнилям выделились 14 образцов: Кузнечанка, Крепыш, Метеор, Матушка, Невский, Лина, Никулинский, Саровский, Сафо, Великан, Г 3-43-2, Любава, Удача и Юна с оценкой - 8 баллов.

Выводы. Самими продуктивными, в среднем за три года, оказались ранний сорт Удача и среднеранний сорт Ильинский с урожайностью 49 и 51т/га. Высокопродуктивными были образцы: Метеор, Любава, Люкс, Невский, C-112-03, Сафо, Танай, Гусар, Златка и Никулинский, с урожаем свыше 45 т/га. По устойчивости к фитофторозу и другим гнилям в хранении выделились сорта: Крепыш, Кузнечанка, Лина, Любава, Невский, Никулинский, Сафо, Сударыня, Удача и Юна.

Благодарности: работа поддержана бюджетным проектом ИЦиГ СО РАН № 0324-2019-0039-C-01.

\section{Список литературы}

1. Земцова М.А. Технологическая оценка сортов картофеля на пригодность для переработки на хрустящий картофель и картофель «фри» / М.А. Земцова, И.И. Тимофеева // Защита картофеля. - 2011. - № 1. -С. 17-20.

2. Потребление картофеля, овощей и продовольственных бахчевых культур на душу населения в год // Сб. регионы России. Социально-экономические показатели Росстат, 2017 [Электронный ресурс].

URL: http://www.gks.ru/bgd/regl/B14_14p/IssWWW.exe/Stg/d01/04-24.htm (дата обращения 10.12.2019).

3. Методические указания по поддержанию и изучению коллекции картофеля 
/под ред. С.Д. Киру - Санкт-Петербург, 2010. - 27 с.

4. Методические положения по проведению оценки сортов и гибридов картофеля на испытательных участках. - М.: Изд-во ВНИИКХ, 2017 - 11 с. [Электронный ресурс]. URL: http://potatoes.biores.cytogen.ru/egi2_documentation (дата обращения 10.12.2019)

5. Доспехов Б.А. Методика полевого опыта (с основами статистической обработки результатов исследований) / 5 изд., перераб. и доп. - М.: Агропромиздат, 1985. - 351 с.

DOI 10.18699/GPB2020-82

\section{Поиск источников засухоустойчивости у льна-долгунца для практических целей селекции культуры}

Богдан В.3. *, к.с.-х.н., зав. лаб. селекичии льна-долгуни̧а, Богдан T.М., к.с.-х.н., в.н.с., Литарная М.А., н.с.

РУП «Институт льна», аг. Устье, Оршанского района, Витебской области, Беларусь

*e-mail: bogdan_v@tut.by

Приведены результаты исследования сортов льна-долгунца по признакам урожайности семян, соломы и волокна в полевом и засушливом фонах в течение 2018-2019 г2. Вылелены высокоадаптивные к засухе сорта Лада, Эден, Сурский, которые с успехом могут использоваться в селекционной работе, направленной на создание сортов с повышенной засухоустойчивостью.

Ключевые слова: лен-долгунеи, сорт, урожайность, засухоустойчивость, адаптивность, коэффициент адаптивности.

\section{Search for sources of dry resistance in fibre-flax for practical purposes of selection of culture}

Bogdan V. Z., Bogdan T. M., Liternaya M. A. RUE "Institute offlax", ag. Ustye of the Orsha district, Vitebsk region, Belarus.

The results of a study of fibre-flax varieties by signs of yield of seeds, straw and fiber in the field and arid backgrounds during 2018-2019 are presented. Highly drought-tolerant varieties of Lada, Eden, and Sursky have been identified, which can be successfully used in breeding work aimed at creating varieties with increased drought tolerance.

Keywords: fibre-flax, variety, yield, drought tolerance, adaptability, adaptability coefficient.

Неблагоприятные факторы, интенсивность действия которых постоянно нарастает, подавляют продуктивность, рост и развитие растений. Воз- 